\title{
Geotechnical analysis and ground support selection for the Ernest Henry crusher chamber
}

\author{
A.D. Campbell Xstrata Copper, Australia \\ C.R. Lilley Beck Engineering Pty Ltd, Australia \\ S. Waters Xstrata Copper, Australia
}

P.A. Jones Xstrata Copper, Australia

\begin{abstract}
The Ernest Henry crusher chamber is a large excavation located at a depth of approximately $1 \mathrm{~km}$. During the pre-feasibility study, a single exploration drill hole was extended below the orebody which identified no adverse ground conditions and the crusher location was set. Additional diamond drilling into the planned crusher chamber location was conducted in 2010 and followed by a geotechnical assessment of the life of mine chamber stability. This analysis found that the planned chamber was located almost entirely within a large fault zone, and that the chamber was likely to be unstable. The chamber was relocated as far as the constraints allowed, which ensured that there was no known fault exposure in the chamber backs although the fault zone was still exposed in the walls. The alternate chamber location was found to be more stable, but it was understood that the poor ground conditions would require heavy ground support to ensure life of mine stability.
\end{abstract}

A detailed geotechnical assessment of the revised chamber location was undertaken to assess stability and support requirements, comprising of core logging, structural mapping, rock mass characterisation, empirical and kinematic stability assessments, simple numerical models and benchmarking against crusher chambers at other mines.

The excavation sequence was set to minimise damage from over-mining, promote stability via the ground support installation sequence and minimise impacts on the mining schedule. Three-dimensional discontinuum non-linear numerical modelling was used to confirm the sufficiency of the proposed excavation design, sequence and ground support system over the entire life of the mine to identify potential problems and additional support requirements before the chamber was mined.

Chamber construction was managed like a civil engineering project with a stringent quality control programme for both mining and ground support. An instrumentation system and on-going monitoring programme were designed to monitor rock mass behaviour and ground support response and compare actual behaviour to the model forecasts.

\section{$1 \quad$ Introduction}

Ernest Henry Mining (EHM) is located $38 \mathrm{~km}$ north east of Cloncurry in the Eastern Fold Belt of the Mount Isa Inlier of North West Queensland as shown in Figure 1. The copper-gold-magnetite orebody is hosted by strong Proterozoic rocks (predominately intermediate and felsic volcanics) which are overlaid by a $50 \mathrm{~m}$ thick cover sequence consisting of sand, clay, shale and gravel. The orebody is approximately cylindrical in shape and dips south at $45^{\circ}$.

The operation consists of an open pit and underground sublevel cave (SLC). The open pit mine operated from 1996 to late 2011 and has final dimensions of 1.5 by $1.3 \mathrm{~km}$ and is approximately $530 \mathrm{~m}$ deep. Underground mine development started in 2008 with first ore production in 2011. The SLC targets ore down dip of the overlying open pit and extends a further $425 \mathrm{~m}$ vertically (or $670 \mathrm{~m}$ down dip) to a depth of almost $1 \mathrm{~km}$. The planned cave footprint on the upper levels is approximately $220 \mathrm{~m}$ by $220 \mathrm{~m}$, but narrows 
to around 220 by $150 \mathrm{~m}$ in the lowest levels. A conceptual layout of the underground mine with respect to the open pit is shown in Figure 2. Initial SLC production is trucked via the decline and in pit portal, building up to a rate of $3 \mathrm{Mtpa}$ in 2013. Excavation of the chamber began in early 2013 and was approximately 50\% completed at the time of writing. SLC production is planned to ramp up to a sustained rate of 6 Mtpa in 2016 following completion of the crusher chamber and ore transfer system to the $936 \mathrm{~m}$ deep hoisting shaft.

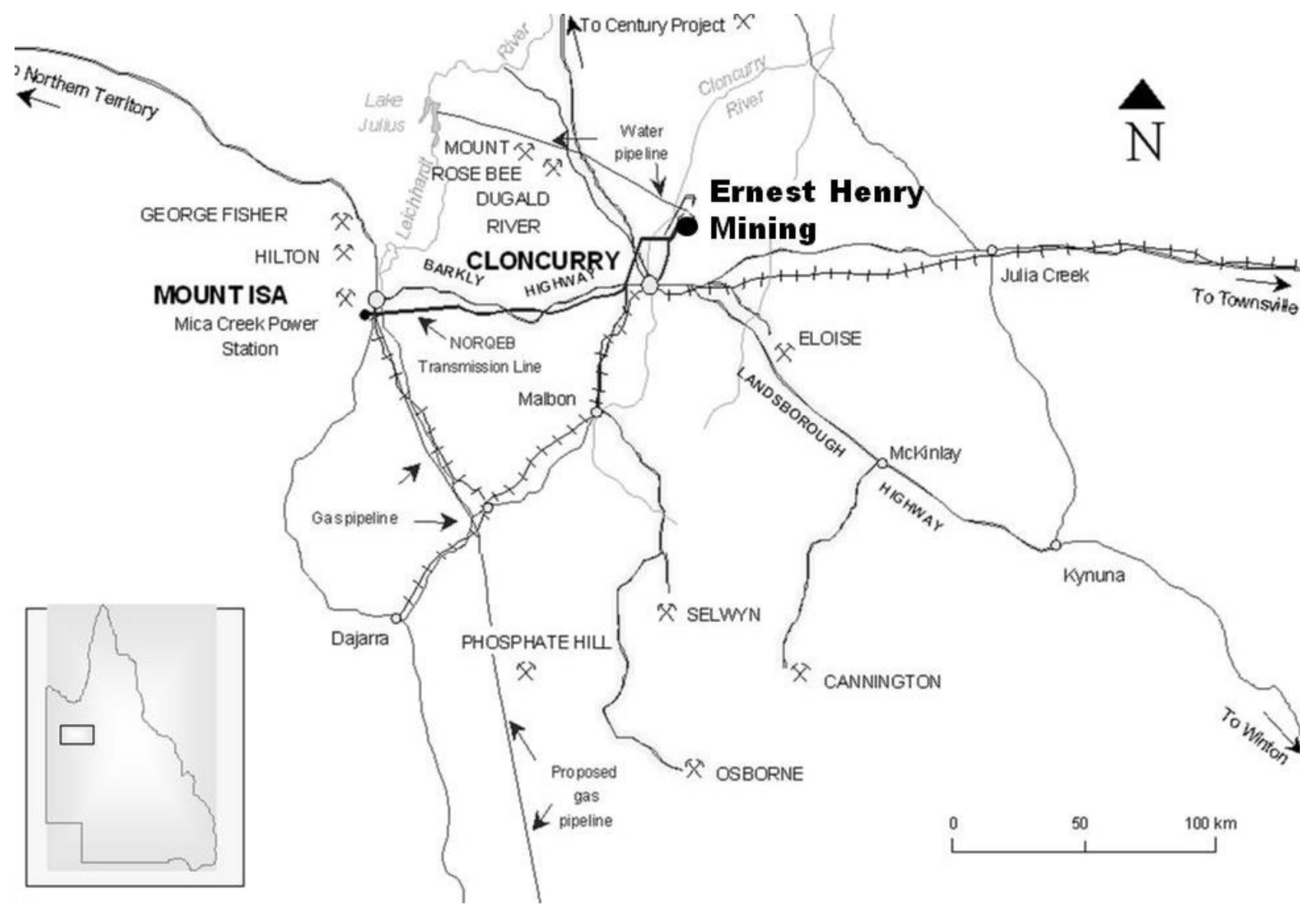

Figure 1 Location of the Ernest Henry mine showing major access roads

Diamond drilling into the crusher precinct in 2010 intersected a large fault zone that had not been identified in earlier studies. The chamber was moved within the constraints imposed by the proximity of the SLC, the tramming level layout and ore pass network as well as equipment such as the transfer conveyor system. Once an alternate location was selected, a preliminary ground support regime was designed and assessed using a combination of empirical methods, kinematic analysis, bench marking from similar crusher chambers and simple numerical modelling. The ground support was upgraded for potential dynamic loading and the excavation sequence designed to expedite construction and minimise the potential for rock mass damage during excavation.

As part of the design confirmation, the crusher geometry and ground support system was modelled using non-linear 3D FE modelling to simulate rock mass and ground support response throughout the chamber precinct over the entire remaining life of the SLC. Model results identified that the preliminary ground support selected needed to be altered to meet predicted load and displacement requirements.

A mining and ground support quality control program was implemented to ensure accurate mining and correct support installation during chamber construction. Geotechnical monitoring systems, though not installed at the time of writing, were designed to monitor the stability of the excavation and provide sufficient data to confirm numerical modelling results. 


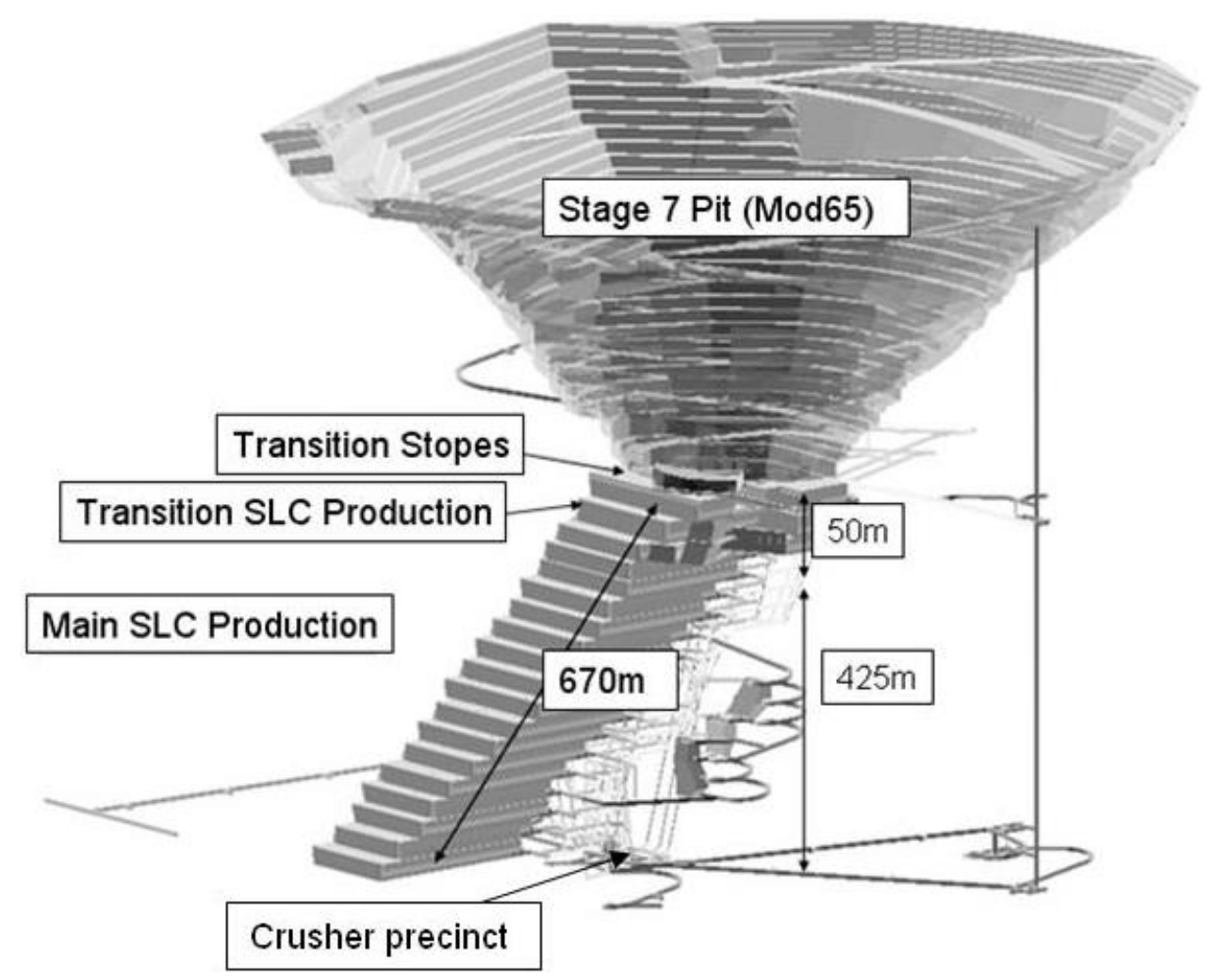

Figure 2 Oblique view of the open pit and underground mine at EHM looking northwest

\section{$2 \quad$ Analysis methodology}

The following methodology was adopted for the geotechnical assessment and ground support design for the crusher chamber:

1. Collection of geology and geotechnical data, including structural data.

2. Rock mass characterisation and specification of rock mass strength parameters.

3. Preliminary ground support selection using empirical schemes, kinematic analysis, benchmarking against crusher chambers at similar mines and simple numerical models.

4. Detailed 3D non-linear numerical modelling to assess rock mass and ground support response throughout the mine life.

5. Assess numerical modelling results and modify the ground support regime (if required) based on modelling results.

6. Finalise excavation and ground support sequence.

7. Assess the impacts of blasting, seismic activity and rock mass deformation and ensure the effects are minimised, monitored and controlled as far as practicably possible.

8. Specify quality control requirements for ground support installation.

9. Design and install systems to monitor displacement, closure, seismicity and damage.

10. Ongoing monitoring and numerical model validation.

\section{$3 \quad$ Initial stability analysis and crusher relocation}

The crusher chamber was first located on the 1125 level (or 1,050 m below surface) during the prefeasibility study, and had a single diamond drill hole through it to investigate the expected ground conditions. No adverse ground conditions were identified during core logging of this drill hole. To reduce 
project capital, the crusher was raised $50 \mathrm{~m}$ to 1175 level. However, the relocation inadvertently placed the chamber within Fault 6 which had not been interpreted at the time due to a lack of drilling into the footwall area.

Fault 6 was discovered in late 2010 when four additional holes drilled below the orebody intersected a zone of jointed rock mass with heavy discing and partial core loss. Preliminary analysis found that the chamber was likely to be unstable in this location (Campbell, 2011). As a result, the crusher chamber was moved a second time to a more favourable location, $20 \mathrm{~m}$ to the south and $10 \mathrm{~m}$ to the west, to reduce its exposure to Fault 6 as shown in Figure 4. This ensured that there was no fault exposure in the backs of the chamber and significantly reduced the fault exposure in the north and east walls, according to the structural interpretation at the time. Unfortunately, the chamber could not be relocated completely away from the fault zone due to restrictions imposed by surrounding infrastructure and the mine design (i.e. the proximity to the SLC, mechanical restrictions of the conveyor system and the ore pass network which had already begun construction). The alternate chamber location was found to be more stable, however, it was likely that the proximity of Fault 6 and potential deformation due to SLC mining would require extensive ground support to ensure life of mine stability.

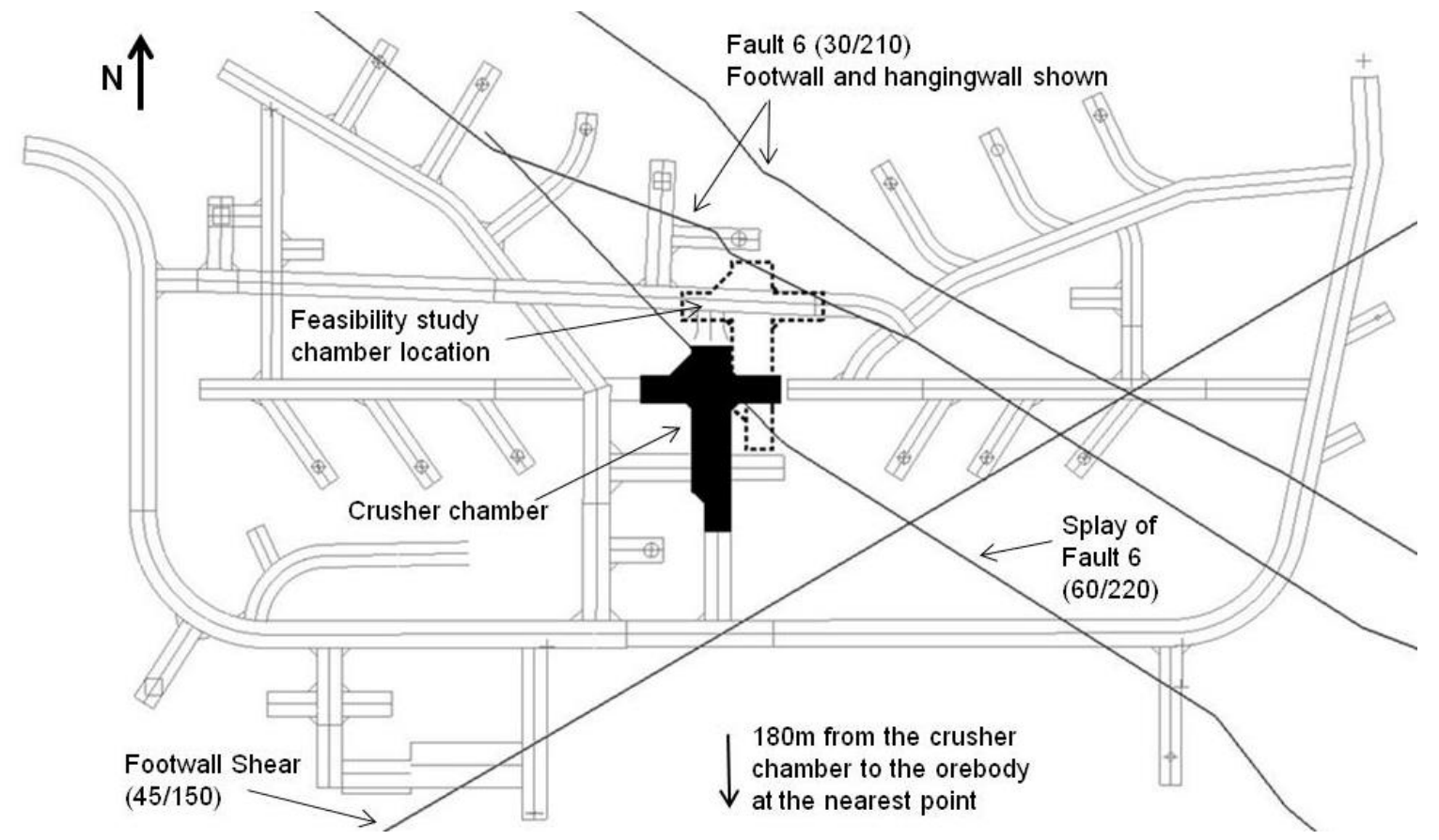

Figure 3 Plan view of the 1,175 haulage level and crusher relocation

\section{$4 \quad$ Preliminary ground support selection}

The crusher chamber is permanent mine infrastructure with large capital investment prompting the excavation and support to be managed like a civil engineering project rather than a mining project. Rehabilitation would be very difficult and costly once mechanical infrastructure was installed and significant ground movement, support failure or rock mass damage has the potential to result in significant down time for the crusher. Considerations for the ground support regime to ensure life of mine stability included:

- Capacity and demand (static and dynamic).

- Potential rock mass failure mechanisms.

- Length, depth of embedment and anchorage type.

- Reinforcement and surface support interaction.

- Excavation and ground support sequence. 
- Equipment capabilities and contractor workforce training.

- Cost, installation time and schedule impacts.

- Quality assurance and quality control.

To reduce the number of ground support design iterations, a preliminary ground support regime was selected using empirical methods, benchmarking against crusher chambers at other mines and simple numerical models (Map3D and Phase2). The performance of the preliminary ground support was then subsequently assessed using non-linear modelling and modified further.

\subsection{Geotechnical setting}

The crusher chamber is hosted in intermediate volcanics and is located in proximity to Fault 6 and the Footwall Shear Zone (FWSZ). Fault 6 is a mine scale structure orientated at approximately 30/210 that underlies the orebody. The Fault 6 zone has a variable thickness between 10 and $25 \mathrm{~m}$ and contains jointed rock mass with intermittent bands of broken rock and clay gouge. A narrow splay of Fault 6 , known as the Angryman fault was interpreted along the hangingwall of the Fault 6 zone. The FWSZ is characterised by increased foliation intensity and quartz veining relative to the surrounding intermediate volcanic rock mass. Previous development through the FWSZ has generally encountered good ground conditions elsewhere in the mine. Structures representing the foliation were included in the discrete fracture network (DFN), but the rock mass properties between the structures were assumed to be the same as the host rock. Rock mass parameters for chamber precinct are provided in Table 1.

Table 1 Rock mass parameters for the intermediate volcanic and Fault 6 zone

\begin{tabular}{ccc}
\hline Q System Parameter & Intermediate Volcanics & Fault 6 \\
\hline UCS & $110 \mathrm{MPa}$ & $110 \mathrm{MPa}$ \\
$\mathrm{E}_{\mathrm{m}}$ & $40 \mathrm{GPa}$ & $10 \mathrm{GPa}$ \\
$\mathrm{v}$ & 0.2 & 0.25 \\
$\mathrm{~m}_{\mathrm{b}} / \mathrm{m}_{\mathrm{i}}$ & 0.4 & 0.16 \\
$\mathrm{~s}$ & 0.062 & 0.003 \\
$\mathrm{a}$ & 0.5 & 0.5 \\
$\mathrm{GSI}$ & 75 & 40 \\
$\mathrm{RQD}$ & $90 \%$ & $50 \%$ (avg.) \\
$\mathrm{J}_{\mathrm{n}}$ & 6 & 9 \\
$\mathrm{~J}_{\mathrm{r}}$ & 2 & 1 \\
$\mathrm{~J}_{\mathrm{a}}$ & 1 & 2 \\
$\mathrm{~J}_{\mathrm{w}}$ & 1 & 0.5 \\
$\mathrm{SRF}$ & 5 & 10 \\
Q value & 6 & 0.2
\end{tabular}

Ten stress measurements have been conducted using multiple methods including ANZI (Mills, 2009), HI cell (Litterbach, 2010), DRA (Dight, 2011) and AE measurements (Villaescusa and Li, 2004; Villaescusa and Machuca, 2011). Five AE measurements were conducted at depths between 270 and $940 \mathrm{~m}$ using exploration drill core. Core samples were taken at considerable distance from the open pit and results are relatively similar to those described by Lee et al. (2010) for the Mt Isa inlier region. It is believed that these results represent the virgin stress state at the site. An additional five stress measurements, including $\mathrm{HI}$ cell 
testing, were conducted in proximity to the orebody and open pit at depths between 320 and $870 \mathrm{~m}$. Results show different principal stress directions to the AE measurements and it is believed that these stress measurements are the open pit mining induced stress state and have been confirmed as accurate by underground observations. Both stress regimes are provided in Tables 2 and 3.

Table 2 Virgin stress regime measured using AE stress testing

\begin{tabular}{cccc}
\hline Principal Stress & Magnitude $(\mathrm{MPa})$ & Dip $\left(^{\circ}\right)$ & Dip Direction $\left(^{\circ}\right)$ \\
\hline$\sigma_{1}$ & $0.0511 \times \operatorname{depth}(\mathrm{m})+2$ & 05 & 212 \\
$\sigma_{2}$ & $0.0365 \times \operatorname{depth}(\mathrm{m})$ & 18 & 303 \\
$\sigma_{3}$ & $0.0228 \times \operatorname{depth}(\mathrm{m})$ & 72 & 107 \\
\hline
\end{tabular}

Table 3 Mining induced stress regime measured using $\mathrm{HI}$ cell testing

\begin{tabular}{cccc}
\hline Principal Stress & Magnitude $(\mathrm{MPa})$ & Dip $\left(^{\circ}\right)$ & Dip Direction $\left(^{\circ}\right)$ \\
\hline$\sigma_{1}$ & $0.051 \times \operatorname{depth}(\mathrm{m})$ & 11 & 279 \\
$\sigma_{2}$ & $0.035 \times \operatorname{depth}(\mathrm{m})$ & 58 & 027 \\
$\sigma_{3}$ & $0.022 \times \operatorname{depth}(\mathrm{m})$ & 30 & 182 \\
\hline
\end{tabular}

\subsection{Empirical ground support selection}

The Q system (Barton et al., 1974) was used to provide an indicative ground support regime. Table 1 shows the $Q$ system parameters used in the assessment. Empirical ground support selection for the chamber assumed that the backs were hosted in intermediate volcanics without fault exposures and that the walls are intersected by Fault 6 . An excavation support ratio (ESR) of 1.3 was used, which is defined for use in long term civil excavations. The rock mass properties for the chamber backs and East and West walls have been plotted on the $Q$ system chart in Figure 4. Empirical assessment specified that the ground support required in the chamber should be:

- Chamber walls - Fibre reinforce shotcrete (FRS) $120 \mathrm{~mm}$ to $150 \mathrm{~mm}$ thick and $4 \mathrm{~m}$ long bolts on a $1.4 \times 1.4 \mathrm{~m}$ pattern.

- Chamber backs - FRS $40 \mathrm{~mm}$ to $100 \mathrm{~mm}$ thick and $2.8 \mathrm{~m}$ long bolts on a $2 \times 2 \mathrm{~m}$ pattern.

This ground support regime is less than indicated from benchmarking of ground support in other crusher chambers. Most of the benchmarked chambers were found to use longer cable bolt reinforcement and thicker FRS in the chamber backs. In addition, the empirically derived rockbolt length is deemed insufficient given the predicted depth of yielded rock mass in the chamber backs and walls indicated by numerical modelling. Whilst the $Q$ system provides a useful first pass ground support assessment, though it is believed that the method has limitations which simplify rock mass properties and do not explicitly account for important factors such as structural conditions, stress orientation, anisotropy, depth of failure, dynamic support requirements and time-dependant deformation. 


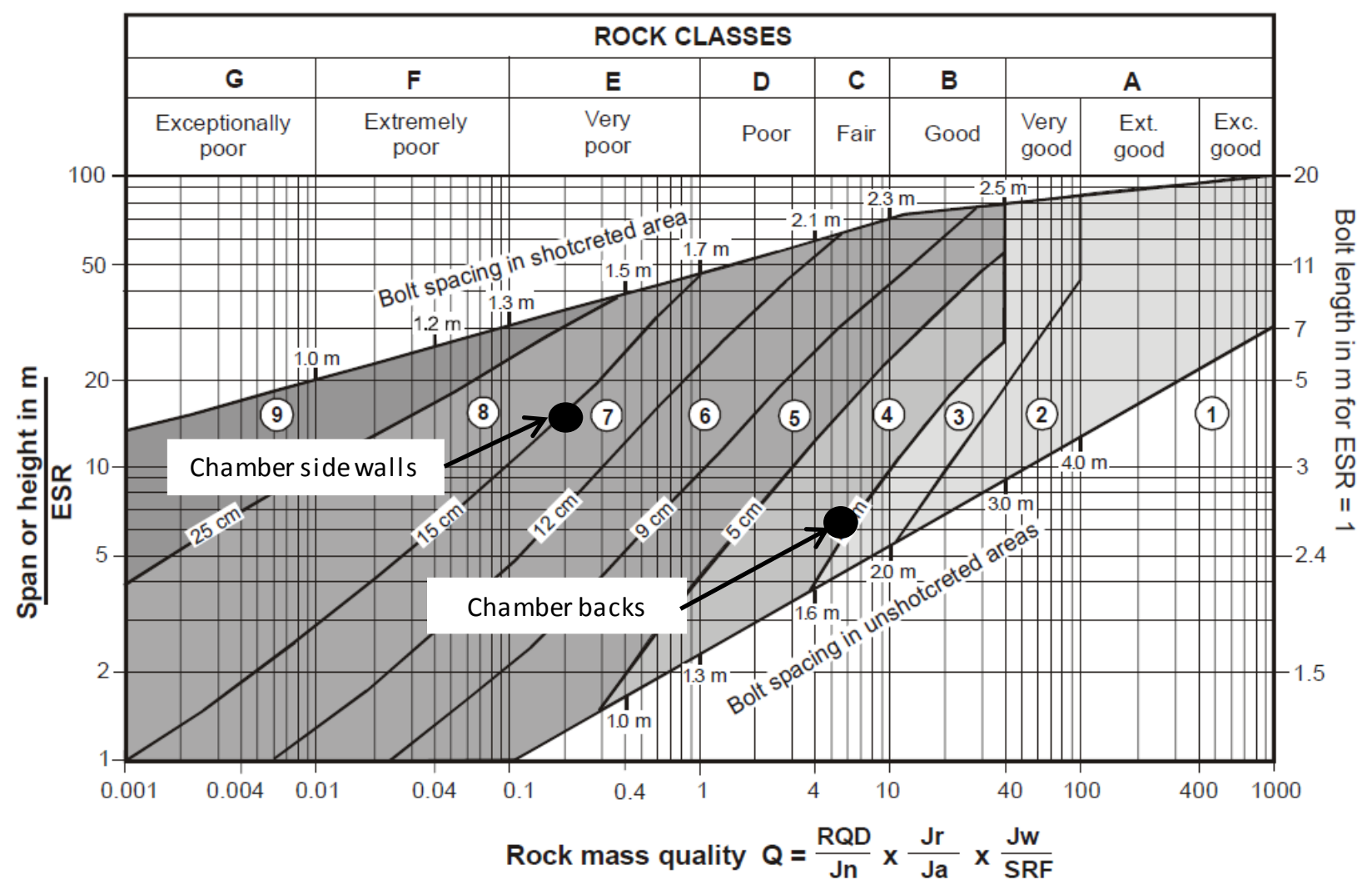

Figure 4 Ground support selection using the $Q$ system (after Grimstad and Barton, 1993)

\subsection{Kinematic analysis}

A kinematic wedge analysis using Unwedge was conducted for the crusher chamber using structural data derived from orientated core and geological mapping of nearby development completed at the time. A joint friction angle of $25^{\circ}$ and zero cohesion were taken as worst case and used in the analysis. Ground support capacity details are specified in Table 4. The FRS shear strength of $200 \mathrm{t} / \mathrm{m}^{2}$ is a conservative value designated by Hoek et al. (1995).

Table 4 Ground support capacity parameters

\begin{tabular}{lcccc}
\hline Support Type & $\begin{array}{c}\text { Tensile } \\
\text { Capacity }\end{array}$ & $\begin{array}{c}\text { Plate } \\
\text { Capacity }\end{array}$ & $\begin{array}{c}\text { Bond } \\
\text { Strength }\end{array}$ & $\begin{array}{c}\text { Shear } \\
\text { Strength }\end{array}$ \\
\hline Posi-mix bolts (20 mm rebar) & $17 \mathrm{t}$ & $20 \mathrm{t}$ & $25 \mathrm{t} / \mathrm{m}$ & $\mathrm{N} / \mathrm{A}$ \\
Cable bolts (twin strand) & $45 \mathrm{t}$ & $50 \mathrm{t}$ & $35 \mathrm{t} / \mathrm{m}$ & $\mathrm{N} / \mathrm{A}$ \\
Fibrecrete $(200 \mathrm{~mm})$ & N/A & N/A & N/A & $200 \mathrm{t} / \mathrm{m}^{2}$ \\
\hline
\end{tabular}

Multiple ground support arrangements were assessed as part of the kinematic wedge analysis. The ground support for the chamber backs and walls consisted of:

- $150 \mathrm{~mm}$ thick FRS.

- $2.4 \mathrm{~m}$ long, $20 \mathrm{~mm}$ resin grouted rockbolts installed on a $1.5 \times 1.5 \mathrm{~m}$ pattern.

- $9 \mathrm{~m}$ long, twin strand $15.2 \mathrm{~mm}$ bulbed cable bolts installed on a $2 \times 2 \mathrm{~m}$ pattern.

The shear strength of the FRS was only applied to fully cured (28 day) shotcrete and the factor of safety increase given by the application of FRS was not applied for short term stability until the curing time was reached. The rockbolt and cable bolt arrangement alone was found to have a minimum factor of safety (FOS) of 1.4. The FRS capacity was included in the long term assessment which indicated a minimum FOS of 
2.4 for all possible wedge combinations. Persistent trace lengths were assumed resulting in worst case wedge geometries being assessed. Structural mapping data collected during excavation of the chamber was used to verify the initial wedge analysis. Mapped structure was found to have persistence lengths less than the initial assessment and no modification to the support regime was required for wedge stability.

\subsection{Preliminary numerical modelling}

Three-dimensional, elastic numerical modelling was used to assess the stress regime and approximate depth of rock mass failure in proximity to the chamber. Two-dimensional, elasto-plastic, modelling was then used to approximate wall deformation and ground support response. Results from preliminary numerical modelling included:

- Rock mass yielding up to $3 \mathrm{~m}$ deep in the chamber walls and up to $2 \mathrm{~m}$ in the chamber backs.

- High stresses in the chamber backs due to the orientation of $\sigma_{1}$, which is subparallel to Fault 6 and subperpendicular to the chamber.

- Low confinement in the walls due to the height of the excavation resulting in the largest forecast displacement within the chamber.

- Yielding of the sill pillar resulting in potential stability issues.

- Movement along Fault 6, particularly the hangingwall contact.

- The forecast closure in the chamber walls was between 150 and $200 \mathrm{~mm}$. Deformation in the chamber backs was generally less than $100 \mathrm{~mm}$.

Overall, preliminary numerical modelling suggested that ground support requirements would be greater than those specified using the $Q$ system, though similar to other benchmarked crusher chambers.

\subsection{Benchmarking of other crusher chambers}

Benchmarking against other mine crusher chambers including Mt Isa Copper Mine, Ridgeway, Cannington, Argyle, Freeport (Casten et al., 2000) and Henderson (Callahan et al., 2000) was carried out with the aim of establishing recent ground support practices. Benchmarking considered the ground conditions, depth, stress regime and chamber dimensions when comparing ground support regimes. The benchmarking showed that typical ground support plans included:

- Twin strand cable bolts, 6 to $12 \mathrm{~m}$ in length depending on the excavation span and expended depth of rock mass damage. Debonded support was used in some chambers where deformation over $150 \mathrm{~mm}$ was expected to occur.

- Cables were generally plated and tensioned using 100 to $200 \mathrm{~mm}$ plates. Cable bolts with partial debonded lengths were twin plated and tensioned.

- Resin grouted rockbolts, 2 to $4 \mathrm{~m}$ in length and between 20 and $35 \mathrm{~mm}$ in diameter. $4.5 \mathrm{~m}$ rockbolts were installed in the Henderson chamber in place of cable bolts. The reason for this is unknown, but suspected to be due to equipment limitations as all ground support was installed using a jumbo.

- FRS thickness between 150 and $200 \mathrm{~mm}$.

- Weld mesh was installed in all chambers. Some operations installed the mesh between FRS layers, while others selected to install the mesh over the FRS linear. The latter was typically where ground conditions were noted as being poor and significant deformation was inevitable. 


\subsection{Preliminary ground support design}

A preliminary ground support design was based on benchmarking, kinematic assessment and preliminary numerical modelling and is somewhat heavier than the empirical assessment suggested. The preliminary ground support design comprised:

- $200 \mathrm{~mm}$ of FRS. Minimum UCS of $40 \mathrm{MPa}$ at 28 days curing and toughness of 400 joules at $40 \mathrm{~mm}$ deflection.

- Weld mesh on exterior of the FRS pinned with $900 \mathrm{~mm}$ long, $46 \mathrm{~mm}$ diameter friction bolts.

- $2.4 \mathrm{~m}$ long, $20 \mathrm{~mm}$ resin grouted rockbolts installed on a $1.5 \mathrm{~m} \times 1.5 \mathrm{~m}$ pattern.

- $9 \mathrm{~m}$ long, $15.2 \mathrm{~mm}$ twin strand cable bolts, installed on a $2 \times 2 \mathrm{~m}$ pattern. Cable bolts have a $3 \mathrm{~m}$ plain strand debonded collar and a $6 \mathrm{~m}$ bulbed toe length. Cables are twin tensioned with $200 \times$ $200 \times 12 \mathrm{~mm}$ plates.

\section{$5 \quad$ Chamber excavation sequence}

The crusher chamber has planned dimensions of $9.5 \mathrm{~m}$ wide, $35 \mathrm{~m}$ long and up to $25 \mathrm{~m}$ high. A top down mining sequence was selected so the chamber could be completely excavated using a jumbo (Figure 5 ). Accurate mining was achieved by taking short $(3 \mathrm{~m})$ development rounds and survey mark-up of the designed excavation perimeter prior to boring each cut. Overbreak and rock mass damage was minimised by using decoupled explosives in all perimeter holes.

The upper portion of the chamber was mined as a single $6.8 \mathrm{~m}$ wide development heading for the full length of the chamber. The second stage of the excavation involved widening the top of the chamber to full width. Development rounds parallel to the final chamber wall were conducted in preference to mass firing the wall stripping to minimise overbreak and rock mass damage. Final thickness FRS, mesh and resin bolts were installed in cycle during the first and second excavation stages while campaign installation of cable bolts was conducted every three to five development rounds, as recommended by geotechnical engineers.

Due to scheduling delays, only the first and second mining stages were completed at the time of writing. The planned excavation steps for the remaining portion of the chamber include:

- Step 3-strip the floor of the initial approach drive and develop the second bench of the chamber using full width development cuts.

- Step 4-access from the northern end of the chamber enabled floor stripping at a grade of 1:6 down. Installation of edge protection and strapping of the sill pillar could then be conducted. During this stage the sill pillar below the initial chamber access was pre supported with cable bolts.

- Step 5-develop the lubrication bay below the sill pillar to access the lower portion of the main chamber. Ramp development up into the chamber at a grade of 1:7 to mine below the current chamber excavation.

- Step 6 - floor strip around the collar of the planned ore bin to final design dimensions. The ore bin is to be drilled using $102 \mathrm{~mm}$ down holes and fired in $3 \mathrm{~m}$ lifts. The ore bin planned to be supported using a shrinkage technique.

Alternative mining sequences were considered during the planning phase of the chamber. Mining the top pass of the chamber to full width as a single heading was not selected as in cycle cable bolting would be required which adversely impacts the mining schedule. A combination of jumbo with long hole mining in the main portion of the chamber was found to provide a shorter excavation time for the chamber. However, this method was not selected due to potential issues such as drilling accuracy, wall control and overbreak, rock mass damage and potential fall out of unsupported edges. A single mass firing of the 
central portion of the chamber also had the potential to result in damaging seismicity due to large, rapid stress change.

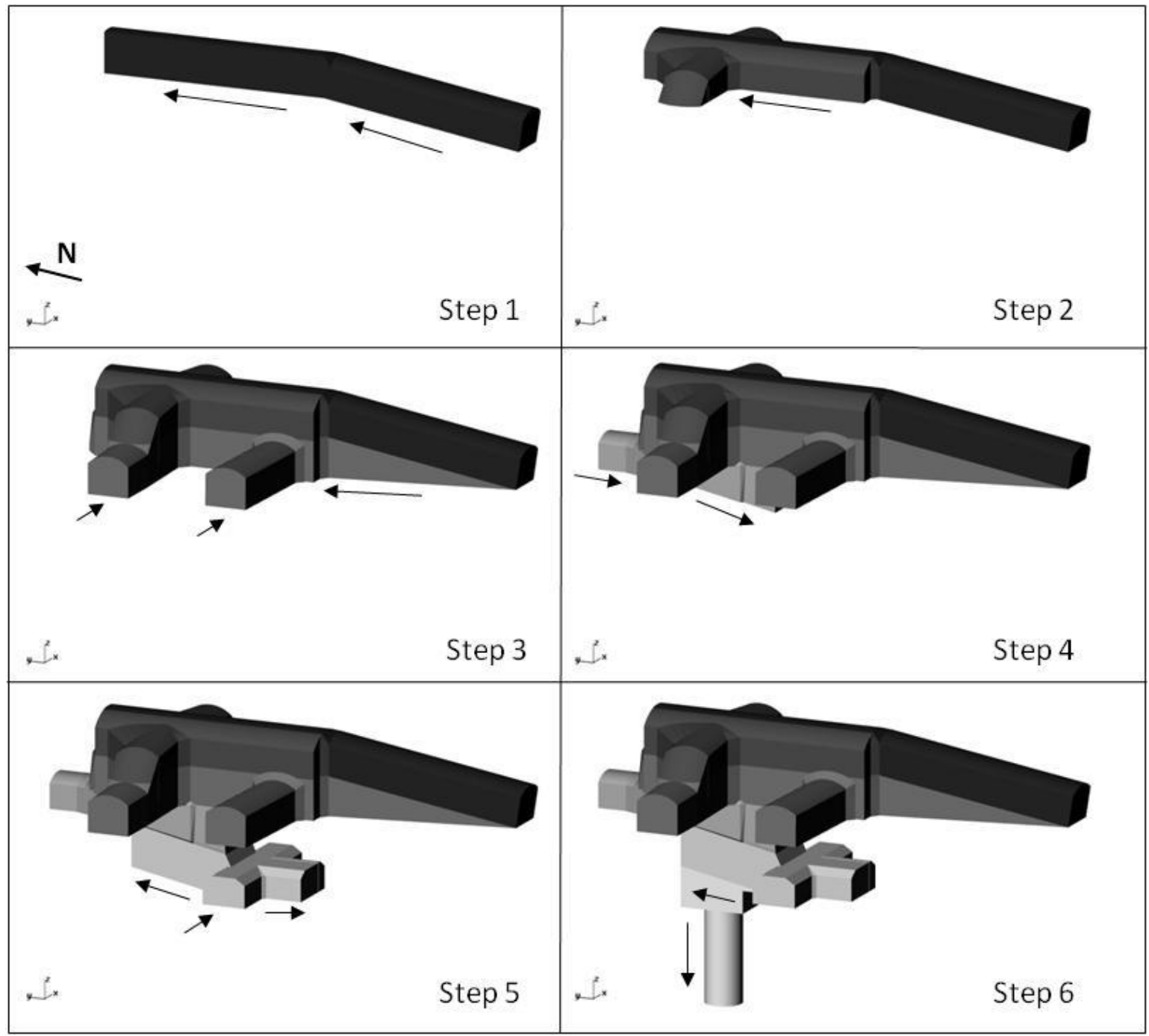

Figure 5 Chamber excavation steps

\section{Experience during development and subsequent design adjustments}

Prior to the non-linear 3D numerical modelling being undertaken, the preliminary ground support design was amended to include $150 \mathrm{~mm}$ of FRS and $3 \mathrm{~m}$ resin bolts. The cable bolt density in the North, East and West walls of the chamber was also increased due to the likely presence of Fault 6 parallel structures.

Development close to Fault 6 had the potential to be subject to seismic ground conditions. Provisions for dynamic capacity in development ground support were made by installing weld mesh over the FRS surface support and debonded cable bolts. Dynamic ground support calculations have been omitted from this paper, however, the ground support was designed to meet an energy demand of $10 \mathrm{~kJ} / \mathrm{m}^{2}$ and dynamic displacement of $100 \mathrm{~mm}$ following parameters for 'moderate' bursting conditions after Kaiser et al. (1998). Destress blasting was also implemented within $10 \mathrm{~m}$ of Fault 6 (and splays of Fault 6 ) to precondition the rock mass and redistribute stress away from successive development faces. De-stress blasting consisted of $6 \mathrm{~m}$ long holes drilled horizontally into the development face in a dice-five pattern. A $3 \mathrm{~m}$ collar is left uncharged and de-stress holes fired at a number one timing with the $3 \mathrm{~m}$ development round.

Initial non-linear modelling was compared to previous modelling results to verify displacement, wall closure and rock mass yielding. Results showed a considerable increase in predicted closure and rock mass yielding 
which was found to be driven by large scale geological structures which were not included in the elastic and two-dimensional modelling techniques.

The first pass ground support regime was increased following the requirement for dynamic ground support capacity in nearby development and initial non-linear modelling results. The final ground support iteration simulated in the non-linear model consisted of:

- $150 \mathrm{~mm}$ thick FRS. Minimum UCS of $40 \mathrm{MPa}$ at 28 days curing and toughness of 400 joules at $40 \mathrm{~mm}$ deflection.

- Weld mesh (on exterior of FRS) pinned with $2.4 \mathrm{~m}$ long, $46 \mathrm{~mm}$ diameter friction bolts.

- $3.0 \mathrm{~m}$ long, $20 \mathrm{~mm}$ diameter resin grouted rockbolts on a nominal $1.5 \times 1.5 \mathrm{~m}$ pattern installed through the mesh.

- Main chamber -9 m long, $15.2 \mathrm{~mm}$ diameter twin strand cable bolts with a $3 \mathrm{~m}$ plain strand debonded collar with a $6 \mathrm{~m}$ bulbed toe length. Cables are twin tensioned with $200 \times 200 \times 12 \mathrm{~mm}$ plates. The cable bolt spacing was:

○ $1.5 \times 1.5 \mathrm{~m}$ collar spacing in the northern, eastern and western walls of the crusher.

$\circ 2.0 \times 2.0 \mathrm{~m}$ collar spacing in the backs and southern wall of the chamber.

- Up hole and down hole twin strand cable bolts installed through the sill pillar on a $1.5 \times 1.5 \mathrm{~m}$ pattern.

- Reinforced concrete edge protection for ledges and to prevent overbreak and damage.

- Expanded steel straps for brows to provide additional support capacity.

Ground support in the chamber access drives includes:

- $100 \mathrm{~mm}$ thick FRS.

- Weld mesh (on exterior of FRS) pinned with $2.4 \mathrm{~m}$ long, $46 \mathrm{~mm}$ diameter friction bolts.

- $3.0 \mathrm{~m}$ long, $20 \mathrm{~mm}$ diameter resin bolts on a nominal $1.5 \times 1.5 \mathrm{~m}$ pattern installed through the mesh.

- $6 \mathrm{~m}$ long, $15.2 \mathrm{~mm}$ bulbed twin strand cable bolts, with a $2 \mathrm{~m}$ debonded collar, twin tensioned with $200 \times 200 \times 12 \mathrm{~mm}$ bearing plates installed on a $2 \times 2 \mathrm{~m}$ collar spacing.

\section{$7 \quad$ Non-linear numerical modelling results}

Three-dimensional finite element (FE) modelling was used to simulate the ground support and rock mass response in the crusher precinct over the remaining mine life, to confirm the sufficiency of the ground support design. ABAQUS software was used, which is a general purpose, 3D, non-linear, continuum or discontinuum FE analysis package designed specifically for analysing large problems with significant plasticity, large displacements and large numbers of material discontinuities (Lilley and Beck, 2012).

The high resolution model required a submodel of the crusher precinct which used boundary conditions provided by an existing mine scale model of the entire Ernest Henry mine. The crusher submodel included the chamber geometry, nearby development, ground support as well as explicit structures (including geological fault interpretations and a discrete fracture network generated from drill core and mapping data). The submodelling approach allowed a large amount of detail to be built for the area of interest, which would be compromised if the full mine geometry also had to be built in the same model.

Results of the numerical modelling can be summarised as follows:

- Damage and deformation was generally controlled by local structure and the geometry of the chamber (Figure 6). 
- Yielding and wedge potential in the sill pillar between the southern access drive and lower lubrication bay.

- Wall closure during chamber excavation and early stages of SLC mining was quite low but increases up to $300 \mathrm{~mm}$ by the end of the mine life. Deformation is predominately caused by movement on structures and rock mass yielding as SLC production approaches the bottom levels of the mine. This amount of wall closure is significantly higher than the preliminary modelling and is likely to be a result of large scale structures being included in both the global mine model and crusher precinct submodel.

- A small proportion of rockbolts yield during chamber excavation. This number increases during SLC mining, particularly the final stages of mining. Very few cable bolts were found to yield during the life of the chamber.

- Minimal damage to the FRS linear during excavation and first half of SLC production ( 6 years). Damage to the FRS liner was shown to progressively increase during the late stages of SLC mining.

Anticipated deformation and potential for yielding of some ground support elements generally occurs late in mine life and monitoring systems are recommended to validate model predictions over time. The nonlinear modelling found the increased ground support regime to be adequate for the planned life of the chamber, however, significant damage and deformation are likely to occur late in the chamber life.

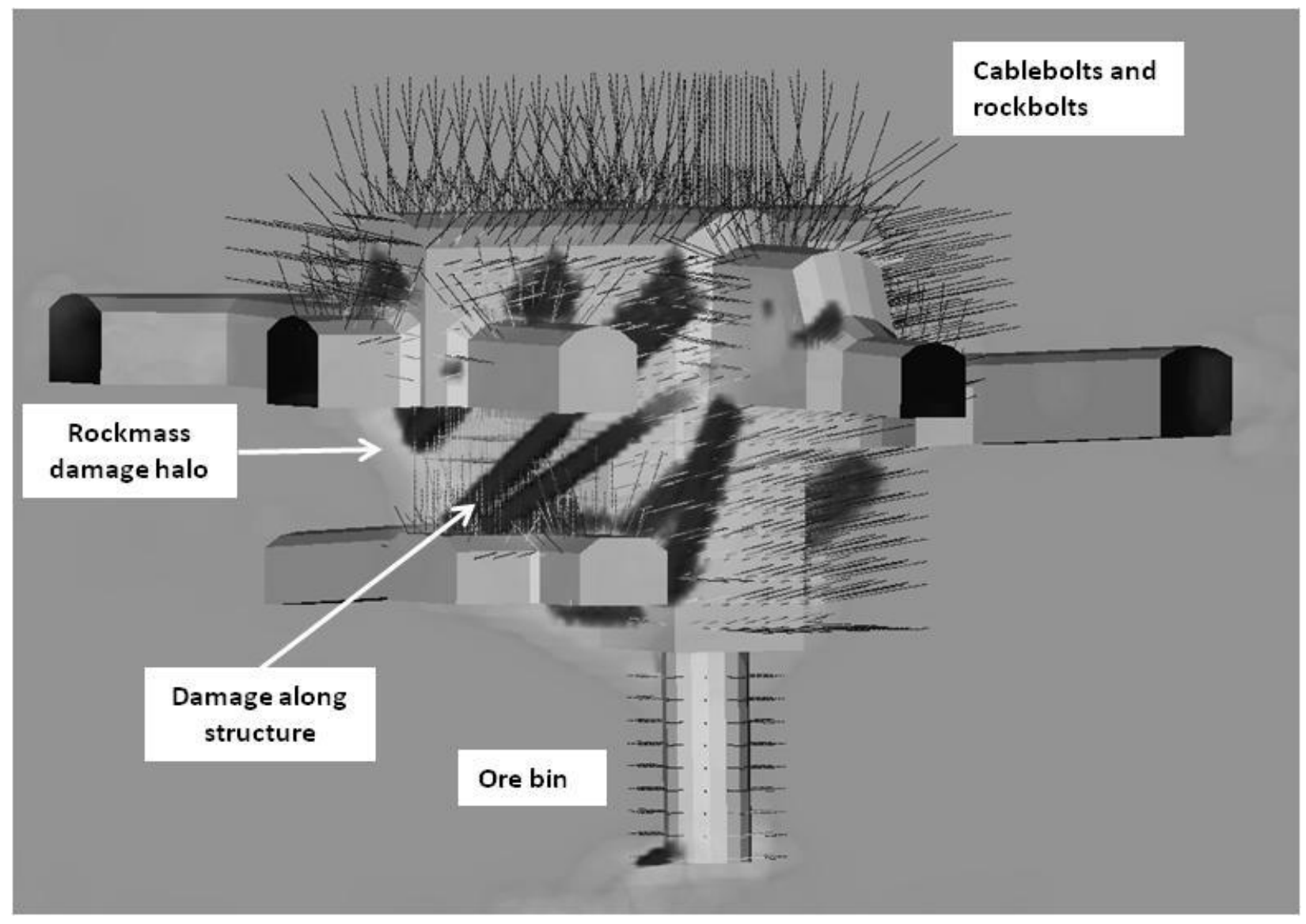

Figure 6 Isometric view of the crusher chamber showing damage

\section{$8 \quad$ Geotechnical monitoring and ground support quality control}

As the chamber was being excavated at the time of writing, monitoring systems had not yet been installed, however, borehole extensometers, SMART cables, survey prisms and regular damage mapping were planned to monitor chamber performance. A high resolution laser scan of the chamber was also planned 
before civil works and mechanical installation. The mine-wide seismic system was also expanded prior to excavation of the chamber to provide high resolution coverage of the area.

Regular sampling and testing of ground support was planned during excavation. Ground support installation audits were also conducted and any inferior ground support was replaced prior to moving onto the next mining step. Ground support quality control measures for the chamber included:

- Depth indicators when spraying FRS followed by thickness testing using an hand drill.

- FRS UCS testing of poured cylinders and cores taken from sprayed panels. Minimum strength of 25 , and $40 \mathrm{MPa}$ at 14 and 28 days respectively.

- FRS toughness testing of round determinant panels. Minimum of 400 Joules at $40 \mathrm{~mm}$ displacement.

- UCS testing of cable bolt grout. Minimum strength of 25 and $40 \mathrm{MPa}$ at 14 and 28 days respectively.

- A minimum $20 \%$ of rockbolts shall be pull tested to $70 \%$ of yield load. Rockbolts that are pull tested shall be checked for resin encapsulation. Any rockbolts that fail are to be replaced. If more than $5 \%$ of rockbolts tested fail, then blanket pull testing of all rockbolts would be conducted.

- A minimum of $20 \%$ of cable bolts shall be pull tested to $70 \%$ of yield load. Any cable bolts that fail are to be replaced. If more than $5 \%$ of cable bolts tested fail, then blanket pull testing of all cables would be conducted.

- Rockbolt and cable bolt spacing shall be checked. Any spacing greater than $200 \mathrm{~mm}$ above design shall be in-filled with missing rockbolts or cable bolts. Cable bolt collars marked up by a surveyor before drilling.

- All rockbolts and cable bolts to be installed within $20^{\circ}$ of design angle.

- Geotechnical sign-off of ground support prior to the next major stage of excavation being completed (i.e. wall stripping, benching, etc.).

All perimeter blast holes, development faces and stripping were marked up by surveyors to minimise over mining and the need for rework. Operator training in ground support quality control requirements was also conducted prior to excavating the chamber.

\section{Conclusions}

The Ernest Henry crusher chamber is a large excavation located at a depth of $1 \mathrm{~km}$ below surface in a complex geotechnical environment including a mine-scale fault, footwall shear zone, variable geology and seismic conditions.

Determining the crusher location and ground support for the chamber was an iterative process enhanced with further information obtained during mine development. In 2010, geotechnical assessments of life of mine chamber stability found that the planned chamber was located almost entirely within a large fault zone, and that the chamber was likely to be unstable. The chamber was moved away from known fault zones and a second geotechnical assessment was undertaken. The alternate chamber location was found to be more stable though the proximity of the fault zones and induced mining stress from the SLC late in the mine life required heavy ground support to ensure the chamber would remain stable for life of mine.

The geotechnical assessments and modelling became more detailed as additional data become available during the two years between the initial assessment and the start of excavation. Chamber stability and ground support requirements were first assessed using empirical and kinematic stability assessments, simple numerical models and benchmarking ground support of other crusher chambers. This enabled site engineers to conduct a first pass geotechnical assessment. Rock mass conditions encountered in proximity to the chamber demonstrated that the ground support system in the chamber would require moderate 
dynamic capacity. Additional drilling, geological fault interpretation and mine development provided sufficient data to enable the use of a three-dimensional discontinuum non-linear numerical model. The more detailed non-linear model enabled the rock mass and ground support response to be simulated over the mine life. This model showed higher levels of rock mass damage and wall deformation than previous models which were not able to include geological structures and accurately capture the global behaviour over the life of mine. This prompted the initial ground support design to be increased to meet predicted support requirements.

Overall, the geotechnical analysis and ground support selection for the Ernest Henry crusher chamber required several iterations. A suite of assessment methodologies were used throughout the assessment process to ensure the chamber was suitably located and adequately supported.

\section{Acknowledgements}

The authors thank Xstrata Copper for permission to publish this paper, the Ernest Henry Mine Planning and Geology teams who provided much assistance during the crusher design and sequencing process, Beck Engineering for providing continual support and advice during the geotechnical assessment process, Brad Simser, Shan van der Merwe (Xstrata Nickel), Dave Counter (Xstrata Copper), Adrian Penny and Mike Sandy (AMC) for their input into dynamic ground support assessment and destress blasting techniques, Glenn Sharrock (Newcrest) for input into crusher ground support benchmarking and Glenn Watt (Rio Tinto) for allowing Xstrata Copper staff to visit the Argyle crusher chambers.

\section{References}

Barton, N., Lieu, R. and Lunde, J. (1974) Engineering Classification of Rockmasses for the Design of Tunnel Support, Rock Mechanics, Vol. 6, pp. 189-236.

Callahan, M.F., Keskimaki, K.W. and Rech, W.D. (2000) A Case History of the Crusher Level Development at Henderson, in Proceedings MassMin 2000, G. Chitombo (ed), 29 October to 2 November 2000, Brisbane, Australia, Australasian Institute of Mining and Metallurgy, Melbourne, pp. 307-316.

Campbell, A.D. (2011) Geotechnical Assessment of the Crusher Chamber, Xstrata Copper, Ernest Henry Mine, Internal document.

Casten, T., Golden, R., Mulyadi, A. and Barber, J. (2000) Excavation Design and Ground Support of the Gyratory Crusher Installation at the DOZ Mine, PT Freeport Indonesia, in Proceedings MassMin 2000, G. Chitombo (ed), 29 October to 2 November 2000, Brisbane, Australia, Australasian Institute of Mining and Metallurgy, Melbourne, pp. 295-299.

Dight, P. (2011) In-situ Stress Measurement Report Hole EH753, The University of Western Australia, Xstrata Copper, Ernest Henry Mine, Internal Report.

Grimstad, E. and Barton, N. (1993) Updating the Q-System for NMT, in Proceedings On sprayed concrete - modern use of wet mix sprayed concrete for underground support, 18-21 October 1993, Fagernes, Norway, Norwegian Concrete Association, Oslo, pp. 46-66.

Hoek, E., Kaiser, P.K., and Bawden, W.F. (1995) Support of underground excavations in hard rock, Balkema, Rotterdam.

Kaiser, P.K., McCreath, D.R. and Tannant, D.D. (1998) Rockburst support chapter, Rockburst Research Handbook, Canadian Rockburst Research Program 1990-1995, Vol. 1.

Lee, M., Mollison, L., Campbell, A. and Litterbach, N. (2010) Rock Stresses in the Australian Continental Tectonic Plate - Variability and Controls, in Proceedings 11th IAEG Congress - Geologically Active New Zealand, C.Y. Chin, C.I. Massey, T.J. McMorran, G.M. Pinches, A.L. Williams (eds), 5-10 September 2010, Auckland, New Zealand, CRC Press, Boca Raton.

Lilley, C.R. and Beck, D.A. (2012) Modelling of the Ernest Henry Mine Crusher Chamber, Xstrata Copper, Ernest Henry Mine, Internal Report.

Litterbach, N. (2010) Ernest Henry Rock Stress Measurement, Mining Measurement Services Pty Ltd, Xstrata Copper, Ernest Henry Mine, Internal Report.

Mills, K. (2009) In-situ stress measurements at stockpile 3 in main decline at Ernest Henry underground Mine, Xstrata Copper, Ernest Henry Mine, Internal Report.

Villaescusa, E. and Machuca, L. (2011) Stress measurements from oriented core using the WASM AE Acoustic Emission method, Xstrata Copper, Ernest Henry Mine, Internal Report.

Villaescusa, E. and Li, J. (2004) Stress measurements from oriented core using the WASM AE Acoustic Emission method, Xstrata Copper, Ernest Henry Mine, Internal Report. 